\title{
Impact of Risk Perception on Trust in Government and Self-Efficiency During COVID-19 pandemic: Does Social Media Content Help Users Adopt Preventative Measures?
}

\author{
Mohammed Salah Hassan ( $\square$ sala142@yahoo.com ) \\ University of Malaya https://orcid.org/0000-0002-1742-2790 \\ Hussam Al Halbusi \\ University of Malaya https://orcid.org/0000-0003-0022-7718 \\ Ali Najem \\ University of Malaya \\ Asbah Razali \\ University of Malaya \\ Kent A. Williams \\ Dalhousie University
}

\section{Research Article}

Keywords: Risk perception, trust in government, self-efficacy, social media, coronavirus, COVID-19

Posted Date: January 19th, 2022

DOI: https://doi.org/10.21203/rs.3.rs-43836/v3

License: (c) (i) This work is licensed under a Creative Commons Attribution 4.0 International License.

Read Full License

Version of Record: A version of this preprint was published at Current Psychology on July 16th, 2020. See the published version at https://doi.org/10.1007/s12144-022-02947-w. 


\section{Abstract}

The public's actions will likely have a significant effect on the course of the novel coronavirus (COVID-19) pandemic. Human behavior is conditioned and shaped by information and people's perceptions. This study investigated the impact of risk perception on trust in government and self-efficacy. It examined whether the use of social media helped people adopt preventive actions during the pandemic. To test this hypothesis, the researchers gathered data from 512 individuals (students and academics) based in Malaysia during the COVID-19 pandemic. Our results suggested that risk perception had a significant effect on trust in government and self-efficacy. Moreover, these correlations were stronger when social media was used as a source for gathering information on COVID-19. In some cases, it even helped users avoid exposure to the virus. This study assessed the relationship between risk perception and the awareness gained from using social media during the pandemic and highlighted how social media usage influences trust in government and self-efficacy.

\section{Introduction}

The current pandemic is caused by severe acute respiratory syndrome coronavirus 2 (SARS-CoV-2). As of mid-April 2020, 2,074,529 confirmed cases and 139,378 deaths had been recorded worldwide, including 5,182 confirmed cases in Malaysia. No treatments or vaccines had been developed, and preventive and quarantine measures were considered the best methods to avoid infection (World Health Organization, 2021). Therefore, preventive measures were promoted at the individual level: regular handwashing, avoiding touching the face, and maintaining an appropriate distance from other individuals ("social distancing"). Many countries promoted social distancing to contain the outbreak (World Health Organization, 2020b).

In Malaysia, the government implemented social distancing by enforcing a movement control order, a set of regulations intended to control the disease's spread. These measures included the immediate suspension of cross-border movements and the closure of public and private schools, universities, and nonessential businesses (Prime Minister's Office of Malaysia, 2020). However, the ability to limit the spread of viruses such as COVID-19 fundamentally depends on how people behave. Therefore, it is vital to collect data on people's perceptions of risk and their behavioral responses during a pandemic and provide information to policymakers on how people respond to public health issues (Slovic, 2000).

It is critical to explore and understand behavioral responses to the risk of infection during a pandemic, especially how people assert their risk perception and how these perceptions shape self-efficacy beliefs. One critical aspect of this exploration is understanding how social media exposure to information affects the relationship between risk perception and self-efficacy (Bandura, 1990b; Chew \& Eysenbach, 2010; Isa et al., 2013). Furthermore, it is essential to provide information to people when public health issues arise so they can understand the risks and respond effectively. Hence, public risk perception and self-efficacy can help individuals understand and manage their responses (Reynolds \& Seeger, 2005; Vos \& Buckner, 2016). 
The media play a critical role in providing information to the public during crises. Sources such as television and newspapers have long shaped people's risk perceptions and self-efficacy during public health crises, as was seen during the H1N1 outbreak (Lin \& Lagoe, 2013). In the information age, social media plays a primary role in how the public acquires information and communicates about crises and catastrophes (Schultz, Utz, \& Göritz, 2011). Notably, the number of people using social media platforms to gather information, especially during a crisis, has dramatically increased (Faustino, Liu, and Jin, 2012). Hence, social media platforms (e.g., Facebook[1], Twitter[2], Instagram[3], YouTube[4], and WhatsApp[5]) have become the primary source of information for many people.

Social media is considered the primary source of health information as well, influencing people's risk perception and self-efficacy in preventive behavior (Barman-Adhikari et al., 2016; Young \& Rice, 2011). Therefore, social media's importance in helping people make sense of the news during public crises needs to be examined. Regarding this, it is crucial to understand whether using social media as a primary source of information shaped the relationship between risk perception and self-efficacy during the COVID-19 pandemic.

[1] Facebook ${ }^{\mathrm{TM}}$ is a trademark of Facebook Inc., registered in the U.S. and other countries.

[2] Twitter $^{\text {TM }}$ is a trademark of Twitter Inc., registered in the U.S. and other countries.

[3] Instagram ${ }^{T M}$ is a trademark of Instagram Inc., registered in the U.S. and other countries.

[4] YouTube ${ }^{\mathrm{TM}}$ is a trademark of Google Inc., registered in the U.S. and other countries.

[5] WhatsApp ${ }^{\text {TM }}$ is a trademark of WhatsApp Inc., registered in the U.S. and other countries.

\section{Theory}

Risk perception

Paek and Hove (2017) defined the concept of "risk perception" as "people's subjective assessment of the possibility that negative outcomes or diseases may occur" (p. 1). Two main dimensions govern this perception: one, the perceived susceptibility dimension, which refers to how people perceive risk and the likelihood of contracting diseases, and two, the severity dimension, which refers to people's ability to process information about risks and understand the seriousness and aggressiveness of diseases (BalogWay \& McComas, 2020; Dryhurst et al., 2020; El-Toukhy, 2015; Pask \& Rawlins, 2016). According to protection motivation theory, susceptibility and severity play important roles in shedding light on risk perception (Rogers, 1983). The two constitute the main dimensions of information when individuals consider the threats from a hazard. The theory assumes that individuals tend to feel pressured to adopt health recommendations to protect themselves from any harm. It further posits that a high level of perceived risk is needed to adopt healthy behaviors during a crisis. Meanwhile, the extended parallel process model (Witte, 1992) highlights that risk perception is a pivotal element that influences behavioral response during a crisis (Rimal \& Real, 2003b).

When people evaluate their susceptibility to the harm they might endure during a crisis, they often make assumptions using a heuristic process. Individuals who are more aware of the risks are also more likely to 
assume that risks occur more frequently than they do (Kahneman, Slovic, \& Tversky, 1982). For instance, when individuals are heavily exposed to media coverage focused on a disease like the H1N1 virus, they tend to have a higher perceived risk of contracting the virus compared to others (Paek \& Hove, 2017). Risk perception is mainly an interpretation and subjective judgment about a current risk (Slovic, 2000). Hence, it is an essential element of risk-based decisions, such as adopting healthy behaviors during a crisis. Therefore, risk perception is explicitly associated with natural disasters, such as hurricanes or pandemics, as well as human-made disasters, such as nuclear radiation exposure (El-Toukhy, 2015; Rimal \& Real, 2003a).

Risk perception has a profound impact on society. How the public assesses the severity and susceptibility of a hazard can influence individual behaviors during a crisis, which profoundly affects the success of any policies and regulations implemented to address the crisis. The outbreak of COVID-19 is no different. Risk perception can substantially impact the precautionary measures that individuals undertake to reduce their exposure to disease transmission. Risk perception shapes people's decision-making in promoting preventive measures during a pandemic (Choi et al., 2017).

Another element of risk perception is optimistic bias; this concept states that individuals tend to believe that the risks posed by a disaster will be less severe for them than for other people. This tendency to underestimate a disaster's adverse effects-underestimating both the probability and the severity-is mainly dependent on the information disseminated regarding a hazard (Weinstein, 1980). Specifically, analyzing risk perception involves individuals' cognitive judgment of their susceptibility to risk. However, such analysis ignores the effect of the information sources in shaping perception. Slovic (2000) argued that perceived susceptibility and severity are generally influenced by individual emotions while making decisions or perceiving risk. Human beings might perceive risk as more threatening when they dread it intensely. Nonetheless, cognitive assessment and emotional judgments are often intense, determining people's risk prospects and behavior (Loewenstein et al., 2001).

Generally, research regarding the factors influencing risk perception has focused on how individual perception is affected by media content and the social, cultural, institutional, and political processes. This widely accepted view highlights that understanding people's risk perception is determined not only by evaluating the scientific information they obtain or their physical experiences with a hazard. McCarthy, Brennan, De Boer, and Ritson (2008) argued that one critical factor affecting risk perception is how the media shape public risk perception. They also cited various factors that affect the public's risk perceptions, such as the media content, amount, tone, and the source's trustworthiness. When public issues arise, people tend to perceive the risks to themselves (Pask \& Rawlins, 2016). Hence, the manifestation of infectious diseases that arise without warning, such as COVID-19, often leads to immediate public perceptions of risk (Oh, Eom, \& Rao, 2015). Thus, examining risk perception is essential to understanding how it shapes self-efficacy beliefs.

Trust in Government 
Citizen's trust in government as a whole is a fundamental topic in the study of social psychology (Hetherington, 1998; Houston et al., 2016; Miller, 1974; van der Meer, 2010; Vigoda-Gadot \& Talmud, 2010). Gamson (1968) defined trust in government as "the probability ... that the political system (or some part of it) will produce preferred outcomes even if left untended" (p. 54). Coleman and Iso-Ahola (1993) described trust as a subcategory of risk: the expectation of gain or loss, which determines whether or not citizens will trust the government. Trust is never absolute but always conditional and contextual (Ruscio, 1996). Cook \& Hardin (1998) argue that citizens often have widely different perceptions and identified two ways citizens can trust their government: one, they can trust everyone in the government as an institution, and two, they can trust that the decisions taken by the government are in the best interest of all citizens. This definition is based on the conceptual framework of game theory and the assumption that granting trust to the government is based on individual interest, so trusting the government depends on individuals' strategies to maximize utility. In short, individuals' trust in the government is based on selfinterest (Blackburn 1998; Levi \& Stoker, 2000).

Trust in government is a critical factor that can determine the success of any policy. Historically, during crises, trust in government has played a crucial role in shaping public behavior-specifically, people's willingness to comply. Trust in government also influences people's support for government policies during crises, specifically health policies (Sankar, Schairer, \& Coffin, 2003; Tomes, 2000). Chanley, Rudolph, and Rahn (2000) argued that public trust in the government is one of the most significant factors influencing public risk perception and ultimately shapes public policymaking. Therefore, trust in government highlights the importance of public support during a crisis. Greater trust levels will minimize conflicts between the public and the government officials enforcing the rules (Metlay, 2013). For example, if the public does not trust their government during a disaster-specifically, a health crisis-there will be a high degree of noncompliance and conflict between the public and the government institutes and their policies. Negative risk perceptions can influence the public will and increase public opposition to government activities during a crisis (Pijawka \& Mushkatel, 1991).

Empirical evidence on epidemics has shown that trust in government is vital to the any policy's success during a crisis. For instance, Slovic, Flynn, and Layman (1991) concluded that trust in government would decrease if the public viewed their government as abusing its power and being dishonest. During the 1894 smallpox outbreak in Milwaukee, Wisconsin, the government forcibly isolated poor immigrants in hospitals but allowed wealthy families to stay at home; thus, trust in government declined and deteriorated, leading to a month-long riot that accelerated the spread of smallpox (Leavitt, 2003). At the core of trust in government during a crisis are the questions of how people trust government agencies and how risk perception shapes public behavior (Smith \& Mayer, 2018). Specifically, research has focused on the effect of risk perception on trust in government, although the number of studies has remained small. Earlier works have examined how risk perception influences trust in government, a crucial link to understanding how people deal with public threats or epidemics (Smith \& Mayer, 2018).

In the COVID-19 pandemic context, the amount of health-related information grew exponentially, and people gathered this information from many different sources. In such cases, their trust in their 
government will likely affect their determination of the risks and benefits associated with the pandemic. In turn, this determination might influence their acceptance of government health measures to combat COVID-19 (Siegrist \& Cvetkovich, 2000). If citizens trust the government responsible for responding to a hazard, their risk perception will be positively influenced. Their trust will help ensure public acceptance of and cooperation with government agencies (Siegrist \& Cvetkovich, 2000; Tumlison, Moyer, \& Song, 2017; Vainio, Paloniemi, \& Varho, 2017). Not surprisingly, studies that have focused on understanding the risk perception of different hazards have found a strong correlation between risk perception and trust in government (Bronfman \& Vázquez, 2011; Keller, Visschers, \& Siegrist, 2012; Vainio et al., 2017).

\section{Self-Efficacy}

Self-efficacy helps shape individuals' ability to overcome a social difficulty (Bandura, 1990a, 1990b). This can be understood as individuals' belief in their ability to manage a difficult task (Bandura, 1997). Bandura (1997) added that the primary understanding of self-efficacy theory is "people's beliefs in their capabilities to produce desired effects by their actions" (p. 7). The theory argues that efficacy belief is a part of psychological adjustments during a crisis. Self-efficacy is evident during public health crises, including the COVID-19 pandemic. It plays a vital role in motivating people during hazards, driving specific changes in their behavior and attitudes (Dorsey, Miller, \& Scherer, 1999). Thus, numerous studies have examined how self-efficacy is shaped by risk perception (e.g., Eisenberger \& Cameron 1996; Coleman \& Iso-Ahola, 1993; Mishra \& Fiddick, 2012).

However, the ability of self-efficacy beliefs to encourage a sense of competence and control over the perceived outcomes of a specific unwanted situation is seen as a higher level of self-efficacy that leads to a greater probability of enacting and adopting health measures during a public health threat (Reid \& Aiken, 2011). Thus, self-efficacy can also be seen as a social construct. Although such constructs can differ depending on culture, individuals' need for control seems universal, and studies have examined how individuals in different cultures practice self-efficacy (Young, Oei, \& Crook, 1991). For example, many studies have examined how self-efficacy changes behavior when dealing with health threats, such as smoking (Carey et al., 1989). Their primary interest concerns people's perceptions and behavioral responses-particularly prevention measures recommended during health crises (Isa et al., 2013; Giritli Nygren \& Olofsson, 2020). Self-efficacy is viewed as a motive and need for control that can also be viewed as a behavior-altering drive. However, this drive is not a permanent personality trait. Self-efficacy is the ability to direct skills to accomplish a desired goal in specific circumstances, usually created by a threat (Chen et al., 2001; Sherer et al., 1982; Smart, Kellaway, \& Worthington, 1984). According to social cognitive theory, self-efficacy is an action motivated from within rather than enforced by an environment. The theory has two central ideas. First, individuals' cognitive capabilities are powerful tools that allow them to develop a course of action based on experience; testing hypothetical actions using our mental capabilities will predict the outcome (Bandura, 2001; Barone, Maddux, \& Snyder, 1997). Second, humans are capable of self-regulation; that is, to achieve a goal, individuals will regulate and change their behaviors. Self-regulation can help people anticipate expectancies and tap past knowledge and experiences to form beliefs about future events (Molden \& Dweck, 2006). 
Therefore, the construct of self-efficacy needs to be studied further. The present study sought to provide a deeper understanding of the relationship between risk perception and self-efficacy during a pandemic. Risk perception and self-efficacy are affected by information regarding a hazard. People gather information regarding a public health issue, which shapes their reactions and behaviors during a crisis (McCarthy et al., 2008; Song et al., 2015).

Perceived Quality of Social Media Content

Traditional media, such as newspapers, radio, and television, were once most people's primary information sources (Dudo, Dahlstrom, \& Brossard, 2007; Paek, Oh, \& Hove, 2016). These media sources are crucial sources of information on public health crises (Lin \& Lagoe, 2013; Oh et al., 2015). Chang (2012) described the association between risk perception during the H1N1 outbreak and the information disseminated by television.

Today, however, social media has transformed how individuals obtain information. Reveling in the rapid and continuous changes in the communications industry, people worldwide have shown an increasing inclination to obtain their information through social media platforms, such as Facebook, Twitter, and WhatsApp. Thus, as Lin, Zhang, Song, and Omori (2016) observed, people primarily obtain their health information during crises from social media platforms, which they consider most convenient. Unlike traditional media, social media enables users to acquire, generate, and share critical health information. For example, many people used social media as a central public platform to discuss and exchange information during the H1N1 outbreak (Davies, 2009). Social media platforms are a primary contributor to people's risk perception about public health crises and provide information that influences their protective health measures (Chung, 2016). Since the H1N1 outbreak, social media has become the primary means for people to express their emotional responses to health issues and virus outbreaks, such as worry and fear (Chew \& Eysenbach, 2010; Signorini, Segre, \& Polgreen, 2011). During the MERS outbreak, social media platforms played a significant role in disseminating factual information, including updates on the systems in place and prevention methods (Song et al., 2015). However, popular and easyto-access platforms are also associated with negative emotional responses to public health issues and are considered a primary contributor to fear and anxiety among the public (Fu \& Zhu, 2020; Paek \& Hove, 2017; Signorini et al., 2011).

Aladwani (2017) found that the perceived quality of social media content encompassed four dimensions: (1) reflective quality, which concerns individuals' beliefs about how the content supports their interests; (2) practiced quality, which concerns how the content meets their needs and shapes their behaviors; (3) advocated quality, which concerns how people's behaviors support and promote the information, and (4) stimulated quality, which concerns individuals' feelings about the content and how it serves their immediate needs.

People's perceptions of the quality of social media content depend on how much they value and trust the information. The primary considerations are considered the content's accuracy and whether the information benefits the users. Risk perception incorporates the susceptibility and severity of public 
hazards (El-Toukhy, 2015). Therefore, social media content's perceived quality shapes perceived susceptibility by providing information about the increasing number of people affected by a particular public health hazard; it shapes perceived severity by focusing on the hazard's adverse impacts, such as death or severe injury (McWhirter \& Hoffman-Goetz, 2016). Hence, exposure to negative information, such as potential pain caused by MERS or H1N1 outbreaks, is positively associated with people's perceived severity of a threat; information about the increasing number of deaths and infections could be associated with perceived susceptibility. Social media content is assumed to increase people's risk perception during a public health crisis (Choi et al., 2017). Vos and Buckner (2016) concluded that social media content plays a critical role in spreading information about a crisis and making sense of public health issues. However, researchers have also cautioned that social media disseminates only limited information on self-efficacy.

Risk perception and self-efficiency also are constructs that depend on the information obtained about a crisis (Agha, 2003). During the early stages of the COVID-19 outbreak in China, conspiracy theories spread around the globe. The resultant racism, panic buying, and inaccurate information have all been linked to the dissemination of information on social media. Widespread misinformation generated panic among the public (Depoux et al., 2020). Subsequently, some social media platforms, such as Facebook, directed users to the expert sources (e.g., the World Health Organization) and myth-buster and fact-checker websites (e.g., FactCheck.org, Snopes.com) to combat misinformation about COVID-19 (Merchant \& Lurie, 2020). Twitter began collating COVID-19 information into lists to make it easy for users to search for updates (Josephson \& Lambe, 2020). Experts suggest that worldwide public panic is best ought with factbased content ("COVID-19: fighting panic", 2020). As a primary source of information, social media can influence public health responses by providing accurate (or inaccurate) content. For example, during China's quarantines following the initial outbreak, the government used social media platforms to provide advice and reassurance to the public about the quarantine rules and to promote its ability to manage the outbreak. Hence, social media can boost awareness of a health hazard, including how to prevent infection by following protective measures (Depoux et al., 2020). As of January 2021, 4.2 billion people worldwide are active social media users (Statista, 2021). Thus, the information shared could reasonably be expected to have shaped the public's decisions during the pandemic and influence their trust in government and self-efficacy beliefs (Depoux et al., 2020; Jin, 2020; Merchant \& Lurie, 2020).

Based on the above information, we formulated the following research hypotheses:

- $\mathrm{H}-1$ : There is a positive relationship between risk perception and trust in government.

- $\quad \mathrm{H}-2$ : There is a positive relationship between risk perception and self-efficacy.

- $\mathrm{H}-3 \mathrm{a}$ : Perceptions of social media content quality moderate the relationship between risk perception and trust in government, such that the relationship is stronger when the perceived quality of social media is higher. 
- $\mathrm{H}-3 \mathrm{~b}$ : Perceptions of social media content quality moderate the relationship between risk perception and self-efficacy, such that the relationship is stronger when the perceived quality of social media quality is higher.

\section{Method}

Sample and Procedure

For data collection, the researchers used an online survey designed using Google Forms which was circulated to students and academics at the University of Malaya (UM) in Kuala Lumpur, Malaysia. The survey was conducted during the Restriction of Movement order (ROM) that began on March 18, 2020. The survey's cover letter explained the purpose of the study and assured the confidentiality of the participants' responses.

Variable Measurement

All the variables were measured using a self-report measure of multi-item scales derived from previous studies. All the measures were assessed using a seven-point Likert-type scale, where $1=$ strongly disagree and 7 = strongly agree (All items are presented in the Appendix 1). Researchers using measures to examine a latent construct must choose carefully between reflective or formative indicators (Becker et al., 2012; Sarstedt et al., 2019). Reflective measurements, commonly recommended when personality and attitudinal variables are modeled, are highly correlated indicators (interchangeable) thought to be caused by a targeted latent construct. The formative measures involve indicators that might determine the construct without necessarily being highly correlated (not interchangeable), making traditional reliability and validity criteria inappropriate and irrelevant (Cheah et al., 2019; Sarstedt et al., 2019). The aforementioned criteria could be applied to distinguish between reflective and formative constructs (i.e., the direction of causality, interchangeability, covariation, and antecedents/consequences of indicators or dimensions) (Sarstedt et al., 2019). The current study encompassed the two types of reflective and formative variables: multiple first-order constructs that represented important aspects of the targeted construct and second-order constructs. Given its complexity, we modeled social media as a second-order formative construct. Determining the type of formative construct is important because excluding any dimensions could alter the conceptual domain (e.g., Becker et al., 2012; Cheah et al., 2019; Sarstedt et al., 2019).

To measure risk perception, we adapted four items from Witte (1996). We reflectively measured risk perception as a first-order construct. We also positioned trust in government as a dependent variable and measured it reflectively using three items as a first-order construct, a method borrowed from Grimmelikhuijsen (2012). We reflectively measured the first-order construct self-efficacy using five items adapted from a prior study (Rimal \& Real, 2003a). Finally, we measured social media content using nine items slightly modified and adapted from Aladwani (2017). Thus, the perceived quality of social media content encompassed four dimensions: reflective quality (two items), practiced quality (two items), advocated quality (three items), and stimulated quality (three items). We reflectively measured these four 
dimensions as first-order constructs. Later, we used them to describe social media's perceived benefits: high scores indicated a stronger perceived benefit of social media content.

Data Analysis and Results

To examine the proposed hypotheses, we used structural equation modeling (SEM) with the partial least squares (PLS) method, using Smart PLS 3.2.8 (Ringle, Wende, \& Becker, 2015). This is a powerful and robust statistical procedure (Henseler, Ringle, \& Sinkovics, 2009). Therefore, this method did not require strict assumptions about the distribution of the variables, making it appropriate for complex causal analyses with both first- and second-order constructs (Hair et al., 2017). To test the statistical significance of the path coefficients, we used the PLS analysis with 5,000 subsamples to generate bootstrap $t$ statistics with $n-1$ degrees of freedom, where (n) was the number of subsamples.

Demographic Analysis

We collected data on the participants' sex, age, education, and job experience. As presented in Table 1, most of the participants were under 35 years old and female; almost half had at least a bachelor's degree.

Common Method Bias Assessment

Common method bias $(\mathrm{CMB})$ refers to variances attributable to the measurement method rather than the constructs being measured, such as when the difference between the trait and the measured scores occurs through using a common method to take more than one measurement of the same or different traits (Podsakoff, MacKenzie, Lee, \& Podsakoff, 2003). CMB could imply a risk in blindly accepting social science research results, given that bias can affect findings due to systematic errors. Thus, in the current research, we attempted to prevent $\mathrm{CMB}$ during the research design phase by applying the procedural remedies proposed by Podsakoff, MacKenzie, \& Podsakoff (2012). Moreover, we used a statistical technique to detect potential CMB situations, namely, a full collinearity test based on variance inflation factors (VIFs) (Kock, 2015). We followed the guidelines described by Kock and Lynn (2012). They proposed that test to assess both vertical and lateral collinearities and indicated that a VIF achieving a value greater than 3.3 would indicate pathological collinearity, warning that CMB might impair the model. Our model's maximum VIF was 2.112 (see Table 2).

\section{Measurement Model Assessment}

To achieve a reflective measurement model, individual item reliability, internal consistency reliability, convergent validity, and discriminant validity must meet specific criteria. In terms of item reliability, the results shown in Table 3 revealed no significant problems. Most items exceeded the recommended level of 0.707 (Hair et al., 2017). To evaluate the constructs' internal consistency, we used composite reliability ranging from 0.847 to 0.916 , higher than the suggested cutoff threshold of 0.70 (Hair et al., 2017). In support of convergent validity, the average variance extracted (AVE) for the constructs ranged from 0.658 to 0.809 , more than the recommended threshold of 0.5 (Hair et al., 2017). For discriminant validity, shown 
in Table 4, we uncovered no issues, as the AVE for each construct was greater than the variance that each construct shared with the other latent variables (Fornell \& Larcker, 1981; Hair et al., 2017).

The formative variables revealed minimal collinearity, as the respective VIFs ranged between 1.264 and 2.932 (see Table 3), far below the standard cutoff threshold of 5 (Hair et al., 2017). Therefore, collinearity did not reach critical levels in any of our formative constructs. Moreover, we examined the significance and relevance of the outer weight's $t$-value and $p$-value of the formative constructs. As shown in Table 3, all the formative indicators were significant (Hair et al., 2017). Thus, our formative measurement model was successful.

\section{Structural Model Assessment}

In explaining the dependent variables of this study (i.e., trust in authority and self-efficacy), none of the demographic variables (i.e., age, sex, and education level) showed a significant effect (see Table 5). Table 5 presents the findings related to $\mathrm{H} 1-\mathrm{H} 3$, which involved the direct and interaction effects. In support of $\mathrm{H} 1$, the direct effect of risk perception was significantly and positively related to self-efficacy $(\beta=0.533, t$ $=4.104, p<0.001$ ); thus, $\mathrm{H} 1$ was supported. $\mathrm{H} 2$ also showed a significant direct effect of risk perception on trust in government $(\beta=0.283, t=2.832, p<0.002)$; therefore, $\mathrm{H} 2$ was also supported.

Regarding the interaction effect, $\mathrm{H} 3 \mathrm{a}$ assumed the interaction effect of risk perception and social media usage on trust in government, for which we found a significant interaction $(\beta=0.210, t=2.289, p<$ $0.011)$. Thus, $\mathrm{H} 3 \mathrm{a}$ was supported. Finally, $\mathrm{H} 3 \mathrm{~b}$ also showed a significant interaction between risk perception and social media on self-efficacy $(\beta=0.506, t=3.571, p<0.001)$. Hence, the second interaction was also supported. To interpret this interaction, we followed Dawson (2014), plotting high versus low social media usage regression lines ( +1 and -1 standard deviation from the mean). This step indicated that the positive relationship between risk perception and trust in government was stronger (a more pronounced slope) when social media usage was high rather than low. Moreover, the positive relationship between risk perception and self-efficacy was stronger when the use of social media was high rather than low.

Regarding its explanatory power, our model revealed moderate to substantial $R^{2}$ values of 0.491 for trust in government and 0.513 for self-efficacy (Hair et al., 2017). We used the Stone-Geisser blindfolding sample-reuse technique to determine the predictive relevance of our model. This technique revealed $Q-$ square values greater than 0 . Thus, our research model effectively predicted both trust in government $\left(Q^{2}\right.$ $=0.220)$ and self-efficacy $\left(Q^{2}=0.241\right)$ (Hair et al., 2017).

\section{Discussion And Conclusion}

This study investigated the impact of risk perception on trust in government and self-efficacy during the COVID-19 pandemic. Significantly, this study introduced the contingent role of social media usage as a critical element during the crisis. In particular, risk perception, trust in the government, and self-efficacy during a public health threat were fundamentally dependent on information regarding the hazard (Vos \& 
Buckner, 2016). Other scholars have highlighted the importance of empirically investigating the potential effects of social media on behavioral responses (Agha, 2003). Hence, the present study provided new information on how social media helped shape the relationship between these constructs during the COVID-19 pandemic. Meanwhile, most governments and international agencies, such as the World Health Organization, adopted social media as a primary conduit for distributing information to the public (Mejia et al., 2020).

Our investigation derived several significant findings. First, risk perception positively influenced our participants' trust in their government (Malaysia). This relationship can be understood as follows: people who perceived the risk of public health hazards were likely to increase their trust in the government during a public crisis (Vaughan \& Tinker, 2009). We also found that individuals demonstrated significant compliance with the Malaysian government's policies to combat the public threat of COVID-19. This finding contributes to the current knowledge of how people might trust their government during a pandemic, highlighting that people's perceived risk will increase their trust in the government during any health crisis, such as the COVID-19 pandemic (Slovic, 2000). In particular, taking into account the trust and confidence model, the public's judgment of risk affected their trust in government and their indirect acceptance of government measures to combat a public hazard. The model also emphasized that people with high trust in the government (in this case, the Malaysian government) were more likely to comply with government measures during a crisis (Siegrist, Earle, \& Gutscher, 2003). Meanwhile, risk perception influenced how the public trusted the government during the pandemic, confirming previous findings (Paek et al., 2008; Vaughan \& Tinker, 2009). Hence, this study concluded that there was a significant link between risk perception and trust in the government.

Second, this study also revealed that risk perception significantly influenced individuals' self-efficacy, in line with previous findings. This relationship highlighted that people's risk perception of COVID-19 positively impacted their self-efficacy; people who perceived higher risk of susceptibility and severity of the outbreak adopted behavioral changes to implement protective measures against the virus (El-Toukhy, 2015). According to the extended parallel process model, individuals who perceive high risk and high efficacy are called responsive individuals (Witte, 1992). These individuals are aware of the severity of and their susceptibility to the disease and are highly motivated to implement preventive measures (Flora et al., 1997). Moreover, according to protection motivation theory, during a crisis, public risk perceptions will be high, which can influence the public to adopt protective measures (van der Weerd et al., 2011; Voeten et al., 2009). Earlier research on this relationship has shown mixed results. Weinstein (1983) and Weinstein, Sandman, \& Roberts (1990) found that risk perception and self-efficacy had a positive relation. However, whereas van der Velde, Hooykaas, \& van der Joop (1992) found that risk perception had a negative correlation with self-efficacy. Rimal and Real (2003b) argued that these results not as contradictory as they sounded since all the findings concerned different public health issues. Hence, our study contributes to the literature by reflecting that the relationship between the risk perception of COVID19 and self-efficacy was significant. 
Third, we found that risk perception was significantly related to trust in the government. However, this relationship must be viewed as dynamic in this era of rapid technological advances, especially when the government has little or no direct control over social network sources or social media content. Our result indicated that the positive relationship between risk perception and trust in government would be stronger with higher social media usage to acquire information on COVID-19. Risk perception and trust in the government fundamentally depended on information regarding a hazard, especially when the government's disseminated information was consistent with that on social media-for example, numbers of infections and recovered cases of COVID-19 (Braun \& Gillespie, 2011). Moreover, Cook \& Hardin (1998) argued that risk perception and trust in government were contingent on the information people acquired during a public threat; that is, the source of information played a critical role in the relationship. In our study, social media usage strengthened the relationship between risk perception and self-efficacy. However, this relationship can be understood as more people becoming aware of the virus's consequences from information gathered from social media, increasing their risk perception of COVID-19 and spurring them to adopt protective measures. Thus, our finding supported the argument that social media could promote healthier behaviors. Our study's results are relevant as they highlight the process through which social media can influence behaviors during a pandemic. We confirmed how social media usage could significantly influence risk perception and self-efficacy (Agha, 2003).

\section{Limitations and Future Research}

The findings of this study should be interpreted with caution in light of several limitations. The first the study's cross-sectional data design. Such a design makes it difficult to provide definitive conclusions regarding causality. However, as this study had to measure sensitive issues, such as the respondents' ethical behavior (Randall \& Gibson, 1990), we needed complete anonymity for the participants (Randall \& Fernandes, 1991), which made it difficult to run a longitudinal analysis (e.g., Podsakoff et al., 2003).

Second, all the respondents were chosen from one institute, the University of Malaya. Future work should expand the scope to include multiple organizations of different types and in different locations. Our approach's one clear advantage was that the data we collected from this distinct sector (students and academics) was more reflective of the broader population than data collected from a more restricted setting, such as a single organization (Randall \& Fernandes, 1991).

Finally, this study was conducted in Malaysia, and the results might be limited to the Malaysian population and government. The results might not be generalizable to other countries owing to geographic, political, cultural, and other differences.

\section{Declarations}

Informed consent: We obtained informed consent from all individual participants included in the study and from the Research Ethics Committee of the University of Malaya. 
Funding: There was no funding for this research project.

Conflict of interest: All authors declare no conflict of interest.

\section{References}

Agha, S. (2003). The impact of a mass media campaign on personal risk perception, perceived selfefficacy and on other behavioural predictors. AIDS care, 15(6), 749762. https://doi.org/10.1080/09540120310001618603

Aladwani, A. (2017). Compatible quality of social media content: Conceptualization, measurement, and affordances. International Journal of Information Management, 37(6), 576582. https://doi.org/10.1016/j.ijinfomgt.2017.05.014

Cook, K., \& Hardin, R. (1998). Introduction. In Levi M. \& Braithwaite V. (Eds.), Trust and Governance (pp. 16). Russell Sage Foundation. http://www.jstor.org/stable/10.7758/9781610440783.4

Bandura, A. (1990a). Perceived self-efficacy in the exercise of control over AIDS infection. Evaluation and Program Planning, 13(1), 9-17. https://doi.org/10.1016/0149-7189(90)90004-G

Bandura, A. (1990b). Perceived self-efficacy in the exercise of personal agency. Journal of Applied Sport Psychology, 2(2), 128-163. https://doi.org/10.1080/10413209008406426

Bandura, A. (1997). Self-efficacy: The exercise of control. New York: W. H. Freeman.

Bandura, A. (2001). Social cognitive theory: An agentic perspective. Annual Review of Psychology, 52(1), 1-26. https://doi.org/10.1146/annurev.psych.52.1.1

Barone, D. F., Maddux, J. E., \& Snyder, C. R. (1997). Self-regulation: The pursuit of goals. In Social Cognitive Psychology. The Plenum Series in Social/Clinical Psychology (pp. 277-303). Boston, MA: Springer. https://doi.org/10.1007/978-1-4615-5843-9_10

Balog-Way, D. H., \& McComas, K. A. (2020). COVID-19: Reflections on trust, tradeoffs, and preparedness. Journal of Risk Research, 23(7-8), 838-848. https://doi.org/10.1080/13669877.2020.1758192

Barman-Adhikari, A., Bowen, E., Bender, K., Brown, S., \& Rice, E. (2016, October). A social capital approach to identifying correlates of perceived social support among homeless youth. Child \& Youth Care Forum, 45(5), 691-708. https://doi.org/10.1007/s10566-016-9352-3

Becker, J.-M., Klein, K., \& Wetzels, M. (2012). Hierarchical latent variable models in PLS-SEM: guidelines for using reflective-formative type models. Long Range Planning, 45(5-6), 359394. https://doi.org/10.1016/j.Irp.2012.10.001 
Bronfman, N. C., \& Vázquez, E. L. (2011). A cross-cultural study of perceived benefit versus risk as mediators in the trust-acceptance relationship. Risk Analysis, 31(12), 1919-

1934. https://doi.org/10.1111/j.1539-6924.2011.01637.x

Braun, J., \& Gillespie, T. (2011). Hosting the public discourse, hosting the public: When online news and social media converge. Journalism Practice, 5(4), 383-

398. https://doi.org/10.1080/17512786.2011.557560

Blackburn, S. (1998). Trust, Cooperation, and Human Psychology. In Cook K. \& Hardin R. (Authors) \& Braithwaite V. \& Levi M. (Eds.), Trust and Governance (pp. 28-45). Russell Sage

Foundation. http://www.jstor.org/stable/10.7758/9781610440783.6

Carey, M. P., Snel, D. L., Carey, K. B., \& Richards, C. S. (1989). Self-initiated smoking cessation: A review of the empirical literature from a stress and coping perspective. Cognitive Therapy and Research, 13(4), 323-341. https://doi.org/10.1007/BF01173477

Chang, C. (2012). News coverage of health-related issues and its impacts on perceptions: Taiwan as an example. Health communication, 27(2), 111-123. https://doi.org/10.1080/10410236.2011.569004

Chanley, V. A., Rudolph, T. J., \& Rahn, W. M. (2000). The origins and consequences of public trust in government: A time series analysis. Public Opinion Quarterly, 64(3), 239-

256. https://doi.org/10.1086/317987

Chen, G., Gully, S. M., \& Eden, D. (2001). Validation of a new general self-efficacy scale. Organizational Research Methods, 4(1), 62-83. https://doi.org/10.1177/109442810141004

Chew, C., \& Eysenbach, G. (2010). Pandemics in the age of Twitter: content analysis of Tweets during the 2009 H1N1 outbreak. PloS ONE, 5(11), e14118. https://doi.org/10.1371/journal.pone.0014118

Choi, D.-H., Yoo, W., Noh, G.-Y., \& Park, K. (2017). The impact of social media on risk perceptions during the MERS outbreak in South Korea. Computers in Human Behavior, 72, 422431. https://doi.org/10.1016/j.chb.2017.03.004

Chung, J. E. (2016). A smoking cessation campaign on Twitter: understanding the use of Twitter and identifying major players in a health campaign. Journal of Health Communication, 21(5), 517526. https://doi.org/10.1080/10810730.2015.1103332

Cheah, J.-H., Ting, H., Ramayah, T., Memon, M. A., Cham, T. H., \& Ciavolino, E. (2019). A comparison of five reflective-formative estimation approaches: reconsideration and recommendations for tourism research. Quality \& Quantity, 53(3), 1421-1458. https://doi.org/10.1007/s11135-018-0821-7

Coleman, D., \& Iso-Ahola, S. E. (1993). Leisure and health: The role of social support and selfdetermination. Journal of Leisure Research, 25(2), 111128. https://doi.org/10.1080/00222216.1993.11969913 
COVID-19: fighting panic with information. [Editorial]. (2020). Lancet, 395(10224), 537. https://doi.org/10.1016/S0140-6736(20)30379-2

Davies, M. (2009, May 1). Swine Flu as social media epidemic; CDC tweets calmly. Digital. https://www.nielsen.com/us/en/insights/article/2009/swine-flu-as-social-media-epidemic-cdctweets-calmly/

Dawson, J. F. (2014). Moderation in management research: What, why, when, and how. Journal of Business and Psychology, 29(1), 1-19. https://doi.org/10.1007/s10869-013-9308-7

Depoux, A., Martin, S., Karafillakis, E., Preet, R., Wilder-Smith, A., \& Larson, H. (2020). The pandemic of social media panic travels faster than the COVID-19 outbreak. Journal of Travel Medicine, 27(3). https://doi.org/10.1093/jtm/taaa031

Dorsey, A. M., Miller, K. I., \& Scherer, C. W. (1999). Communication, risk behavior, and perceptions of threat and efficacy: A test of a reciprocal model. Journal of Applied Communication Research, 27(4), 377395. https://doi.org/10.1080/00909889909365546

Dudo, A. D., Dahlstrom, M. F., \& Brossard, D. (2007). Reporting a potential pandemic: A risk-related assessment of avian influenza coverage in US newspapers. Science Communication, 28(4), 429454. https://doi.org/10.1177/1075547007302211

Dryhurst, S., Schneider, C. R., Kerr, J., Freeman, A. L., Recchia, G., van der Bles, A. M., Spiegelhalter, D., \& van der Linden, S. (2020). Risk perceptions of COVID-19 around the world. Journal of Risk Research, 23(7-8), 994-1006. https://doi.org/10.1080/13669877.2020.1758193

El-Toukhy, S. (2015). Parsing susceptibility and severity dimensions of health risk perceptions. Journal of Health Communication, 20(5), 499-511. https://doi.org/10.1080/10810730.2014.989342

Flora, J. A., Saphir, M. N., Schooler, C., \& Rimal, R. N. (1997). Toward a framework for intervention channels: Reach, involvement, and impact. Annals of Epidemiology, 7(7, Suppl.), S104S112. https://doi.org/10.1016/S1047-2797(97)80013-0

Fornell, C., \& Larcker, D. F. (1981). Evaluating structural equation models with unobservable variables and measurement error. Journal of Marketing Research, 18(1), 39-50. https://doi.org/10.2307/3151312

Fu, K., \& Zhu, Y. (2020). Did the world overlook the media's early warning of COVID-19? Journal of Risk Research, 23(7-8), 1047-1051. https://doi.org/10.1080/13669877.2020.1756380

Gamson, W. A. (1968). Power and discontent. Homewood, IL: Dorsey Press.

Giritli Nygren, K., \& Olofsson, A. (2020). Managing the COVID-19 pandemic through individual responsibility: The consequences of a world risk society and enhanced ethopolitics. Journal of Risk Research, 23(7-8), 1031-1035. https://doi.org/10.1080/13669877.2020.1756382 
Grimmelikhuijsen, S. (2012). Linking transparency, knowledge and citizen trust in government: An experiment. International Review of Administrative Sciences, 78(1), 50-

73. https://doi.org/10.1177/0020852311429667

Cook, K., \& Hardin, R. (1998). Communal and Exchange Trust Norms: Their Value Base and Relevance to Institutional Trust. In Braithwaite V. \& Levi M. (Eds.), Trust and Governance (pp. 46-74). Russell Sage Foundation. http://www.jstor.org/stable/10.7758/9781610440783.7

Hetherington, M. J. (1998). The political relevance of political trust. American Political Science Review, 92(4), 791-808. https://doi.org/10.2307/2586304

Houston, D. J., Aitalieva, N. R., Morelock, A. L., \& Shults, C. A. (2016). Citizen trust in civil servants: A crossnational examination. International Journal of Public Administration, 39(14), 1203-

1214. https://doi.org/10.1080/01900692.2016.1156696

Henseler, J., Ringle, C. M., \& Sinkovics, R. R. (2009). The use of partial least squares path modelling in international marketing. In R. R. Sinkovics \& P. N. Ghauri (Eds.), New challenges to international marketing (Advances in International Marketing, Vol. 20, pp. 277-319). Bingley:

Emerald. https://doi.org/10.1108/S1474-7979(2009)0000020014

Hair, J. F., Hult, G. T. M., Ringle, C., \& Sarstedt, M. (2017). A primer on partial least squares structural equation modeling (PLS-SEM) (2nd ed.). Thousand Oaks, CA: SAGE.

Isa, A., Loke, Y. K., Smith, J. R., Papageorgiou, A., \& Hunter, P. R. (2013). Mediational effects of self-efficacy dimensions in the relationship between knowledge of dengue and dengue preventive behaviour with respect to control of dengue outbreaks: A structural equation model of a cross-sectional survey. PLOS Neglected Tropical Diseases, 7(9), e2401. https://doi.org/10.1371/journal.pntd.0002401

Jin, K.-X. (2020, December 18). Keeping people safe and informed about the coronavirus. Facebook newsroom. https://about.fb.com/news/2020/12/coronavirus/

Josephson, A., \& Lambe, E. (2020, March 11). Brand communications in time of crisis. Twitter blog. https://blog.twitter.com/en_us/topics/company/2020/Brand-communications-in-time-of-crisis.html

Kahneman, D., Slovic, P., \& Tversky, A. (1982). Judgment under uncertainty: Heuristics and biases. New York, NY: Cambridge University Press.

Keller, C., Visschers, V., \& Siegrist, M. (2012). Affective imagery and acceptance of replacing nuclear power plants. Risk Analysis, 32(3), 464-477. https://doi.org/10.1111/j.1539-6924.2011.01691.x

Kock, N. (2015). Common method bias in PLS-SEM: A full collinearity assessment approach. International Journal of e-Collaboration (IJeC), 11(4), 1-10. https://doi.org/10.4018/ijec.2015100101 
Kock, N., \& Lynn, G. S. (2012). Lateral collinearity and misleading results in variance-based SEM: An illustration and recommendations. Journal of the Association for Information Systems, 13(7), Article 2. https://doi.org/10.17705/1jais.00302

Leavitt, J. W. (2003). Public resistance or cooperation? A tale of smallpox in two cities. Biosecurity and Bioterrorism: Biodefense Strategy, Practice, and Science, 1(3), 185192. https://doi.org/10.1089/153871303769201833

Levi, M., \& Stoker, L. (2000). Political trust and trustworthiness. Annual Review of Political Science, 3(1), 475-507. https://doi.org/10.1146/annurev.polisci.3.1.475

Lin, C. A., \& Lagoe, C. (2013). Effects of news media and interpersonal interactions on H1N1 risk perception and vaccination intent. Communication Research Reports, 30(2), 127136. https://doi.org/10.1080/08824096.2012.762907

Liu, B. F., Fraustino, J. D., \& Jin, Y. (2016). Social Media Use During Disasters: How Information Form and Source Influence Intended Behavioral Responses. Communication Research, 43(5), 626646. https://doi.org/10.1177/0093650214565917

Lin, W.-Y., Zhang, X., Song, H., \& Omori, K. (2016). Health information seeking in the Web 2.0 age: Trust in social media, uncertainty reduction, and self-disclosure. Computers in Human Behavior, 56, 289294. https://doi.org/10.1016/j.chb.2015.11.055

Loewenstein, G. F., Weber, E. U., Hsee, C. K., \& Welch, N. (2001). Risk as feelings. Psychological Bulletin, 127(2), 267-286. https://doi.org/10.1037/0033-2909.127.2.267

McCarthy, M., Brennan, M., De Boer, M., \& Ritson, C. (2008). Media risk communication-what was said by whom and how was it interpreted. Journal of Risk Research, 11(3), 375394. https://doi.org/10.1080/13669870701566599

McWhirter, J. E., \& Hoffman-Goetz, L. (2016). Application of the health belief model to US magazine text and image coverage of skin cancer and recreational tanning (2000-2012). Journal of Health Communication, 21(4), 424-438. https://doi.org/10.1080/10810730.2015.1095819

Mejia, C. R., Ticona, D., Rodriguez-Alarcon, J. F., Campos-Urbina, A. M., Catay-Medina, J. B., Porta-Quinto, T., Garayar-Peceros, H., Ignacio-Quinte, C., Carranza Esteban, R. F., Ruiz Mamani, P. G., \& Tovani-Palone, M. R. (2020). The media and their informative role in the face of the coronavirus disease 2019 (COVID-19): Validation of fear perception and magnitude of the issue (MED-COVID-19). Electronic Journal of General Medicine, 17(6), em239. https://doi.org/10.29333/ejgm/7946

Merchant, R., \& Lurie, N. (2020). Social media and emergency preparedness in response to novel coronavirus. JAMA, 323(20), 2011-2012. https://doi.org/10.1001/jama.2020.4469 
Metlay, D. (2013). Institutional trust and confidence: A journey into a conceptual quagmire. In G. Cvetkovich, R. E. Lofstedt (Eds.), Social trust and the management of risk (pp. 114-130). London: Routledge.

Miller, A. H. (1974). Political issues and trust in government: 1964-1970. The American Political Science Review, 68(3), 951-972. Retrieved

from https://web.stanford.edu/class/polisci92n/readings/oct30.1.miller.jstor.pdf

Mishra, S., \& Fiddick, L. (2012). Beyond gains and losses: The effect of need on risky choice in framed decisions. Journal of Personality and Social Psychology, 102(6), 1136-

1147. https://doi.org/10.1037/a0027855

Molden, D. C., \& Dweck, C. S. (2006). Finding "meaning" in psychology: A lay theories approach to selfregulation, social perception, and social development. American Psychologist, 61(3), 192203. https://doi.org/10.1037/0003-066X.61.3.192

Oh, O., Eom, C., \& Rao, H. R. (2015). Research note-Role of social media in social change: An analysis of collective sense making during the 2011 Egypt revolution. Information Systems Research, 26(1), 210223. https://doi.org/10.1287/isre.2015.0565

Paek, H.-J., Hilyard, K., Freimuth, V. S., Barge, J. K., \& Mindlin, M. (2008). Public support for government actions during a flu pandemic: lessons learned from a statewide survey. Health Promotion Practice, 9(4, Suppl.), 60S-72S. https://doi.org/10.1177/1524839908322114

Paek, H., \& Hove, T. (2017, March 29). Risk Perceptions and Risk Characteristics. Oxford Research Encyclopedia of Communication.

https://oxfordre.com/communication/view/10.1093/acrefore/9780190228613.001.0001/acrefore9780190228613-e-283

Paek, H.-J., Oh, S.-H., \& Hove, T. (2016). How fear-arousing news messages affect risk perceptions and intention to talk about risk. Health Communication, 31(9), 1051-

1062. https://doi.org/10.1080/10410236.2015.1037419

Pask, E. B., \& Rawlins, S. T. (2016). Men's intentions to engage in behaviors to protect against human papillomavirus (HPV): Testing the risk perception attitude framework. Health Communication, 31(2), 139149. https://doi.org/10.1080/10410236.2014.940670

Pijawka, K. D., \& Mushkatel, A. H. (1991). Public opposition to the siting of the high-level nuclear waste repository: The importance of trust. Review of Policy Research, 10(4), 180-

194. https://doi.org/10.1111/j.1541-1338.1991.tb00289.x

Podsakoff, P. M., MacKenzie, S. B., \& Podsakoff, N. P. (2012). Sources of method bias in social science research and recommendations on how to control it. Annual Review of Psychology, 63, 539- 
569. https://doi.org/10.1146/annurev-psych-120710-100452

Podsakoff, P. M., MacKenzie, S. B., Lee, J. Y., \& Podsakoff, N. P. (2003). Common method biases in behavioural research: A critical review of the literature and recommended remedies. Journal of Applied Psychology, 88(5), 879-903. https://doi.org/10.1037/0021-9010.88.5.879

Prime Minister's Office of Malaysia. (2020). Movement Control Order: FAQ \& Info. https://www.pmo.gov.my/tag/rmo/

Randall, D. M., \& Fernandes, M. F. (1991). The social desirability response bias in ethics research. Journal of Business Ethics, 10(11), 805-817. https://doi.org/10.1007/BF00383696

Randall, D. M., \& Gibson, A. M. (1990). Methodology in business ethics research: A review and critical assessment. Journal of Business Ethics, 9(6), 457-471. https://doi.org/10.1007/BF00382838

Reid, A. E., \& Aiken, L. S. (2011). Integration of five health behaviour models: Common strengths and unique contributions to understanding condom use. Psychology \& Health, 26(11), 14991520. https://doi.org/10.1080/08870446.2011.572259

Reynolds, B., \& Seeger, M. W. (2005). Crisis and emergency risk communication as an integrative model. Journal of Health Communication, 10(1), 43-55. https://doi.org/10.1080/10810730590904571

Ringle, C. M., Wende, S., \& Becker, J.-M. (2015). SmartPLS 3. Bonningstedt:

SmartPLS. http://www.smartpls.com

Rimal, R. N., \& Real, K. (2003a). Perceived risk and efficacy beliefs as motivators of change: Use of the risk perception attitude (RPA) framework to understand health behaviors. Human Communication Research, 29(3), 370-399. https://doi.org/10.1111/j.1468-2958.2003.tb00844.x

Rimal, R. N., \& Real, K. (2003b). Understanding the influence of perceived norms on behaviors. Communication Theory, 13(2), 184-203. https://doi.org/10.1111/j.1468-2885.2003.tb00288.x

Rogers, R. W. (1983). Cognitive and physiological processes in fear appeals and attitude change: A revised theory of protection motivation. In J. Cacioppo \& R. Petty (Eds.), Social Psychophysiology (pp. 153-177). New York, NY: Guilford Press.

Ruscio, K. P. (1996). Trust, democracy, and public management: A theoretical argument. Journal of Public Administration Research and Theory, 6(3), 461-

477. https://doi.org/10.1093/oxfordjournals.jpart.a024321

Sankar, P., Schairer, C., \& Coffin, S. (2003). Public mistrust: The unrecognized risk of the CDC Smallpox Vaccination Program. The American Journal of Bioethics, 3(4), 2225. https://doi.org/10.1162/152651603322614742 
Sarstedt, M., Hair, J. F., Cheah, J.-H., Becker, J.-M., \& Ringle, C. M. (2019). How to specify, estimate, and validate higher-order constructs in PLS-SEM. Australasian Marketing Journal, 27(3), 197211. https://doi.org/10.1016/j.ausmj.2019.05.003

Schultz, F., Utz, S., \& Göritz, A. (2011). Is the medium the message? Perceptions of and reactions to crisis communication via twitter, blogs and traditional media. Public Relations Review, 37(1), 2027. https://doi.org/10.1016/j.pubrev.2010.12.001

Sherer, M., Maddux, J. E., Mercandante, B., Prentice-Dunn, S., Jacobs, B., \& Rogers, R. W. (1982). The selfefficacy scale: Construction and validation. Psychological Reports, 51(2), 663671. https://doi.org/10.2466/pr0.1982.51.2.663

Siegrist, M., \& Cvetkovich, G. (2000). Perception of hazards: The role of social trust and knowledge. Risk Analysis, 20(5), 713-720. https://doi.org/10.1111/0272-4332.205064

Siegrist, M., Earle, T. C., \& Gutscher, H. (2003). Test of a trust and confidence model in the applied context of electromagnetic field (EMF) risks. Risk Analysis, 23(4), 705-716. https://doi.org/10.1111/15396924.00349

Signorini, A., Segre, A. M., \& Polgreen, P. M. (2011). The use of Twitter to track levels of disease activity and public concern in the US during the influenza A H1N1 pandemic. PloS ONE, 6(5), e19467. https://doi.org/10.1371/journal.pone.0019467

Slovic, P., Flynn, J. H., \& Layman, M. (1991). Perceived risk, trust, and the politics of nuclear waste. Science, 254(5038), 1603-1607. https://doi.org/10.1126/science.254.5038.1603

Slovic, P. (2000). The perception of risk. Abingdon, Oxon and New York, NY: Routledge/Earthscan.

Smart, J. D., Kellaway, I. W., \& Worthington, H. E. C. (1984). An in-vitro investigation of mucosa-adhesive materials for use in controlled drug delivery. Journal of Pharmacy and Pharmacology, 36(5), 295299. https://doi.org/10.1111/j.2042-7158.1984.tb04377.x

Smith, E. K., \& Mayer, A. (2018). A social trap for the climate? Collective action, trust and climate change risk perception in 35 countries. Global Environmental Change, 49, $140-$ 153. https://doi.org/10.1016/j.gloenvcha.2018.02.014

Song, J., Song, T. M., Seo, D.-C., Jin, D.-L., \& Kim, J. S. (2015). Social big data analysis of information spread and perceived infection risk during the 2015 Middle East respiratory syndrome outbreak in South Korea. Cyberpsychology, Behavior, and Social Networking, 20(1), 22-

29. https://doi.org/10.1089/cyber.2016.0126

Statista. (2021, March 5). Worldwide digital population as of January 2021. Retrieved from https://www.statista.com/statistics/617136/digital-population-worldwide/ 
Tomes, N. (2000). The making of a germ panic, then and now. American Journal of Public Health, 90(2), 191-198. https://doi.org/10.2105/ajph.90.2.191

Tumlison, C., Moyer, R. M., \& Song, G. (2017). The origin and role of trust in local policy elites' perceptions of high-voltage power line installations in the state of Arkansas. Risk analysis, 37(5), 10181036. https://doi.org/10.1111/risa.12662

Vainio, A., Paloniemi, R., \& Varho, V. (2017). Weighing the risks of nuclear energy and climate change: Trust in different information sources, perceived risks, and willingness to pay for alternatives to nuclear power. Risk Analysis, 37(3), 557-569. https://doi.org/10.1111/risa.12640

van der Meer, T. (2010). In what we trust? A multi-level study into trust in parliament as an evaluation of state characteristics. International Review of Administrative Sciences, 76(3), 517536. https://doi.org/10.1177/0020852310372450

van der Velde, F. W., Hooykaas, C., \& van der Joop, P. (1992). Risk perception and behavior: Pessimism, realism, and optimism about AIDS-related health behavior. Psychology and Health, 6(1-2), 2338. https://doi.org/10.1080/08870449208402018

van der Weerd, W., Timmermans, D. R., Beaujean, D. J., Oudhoff, J., \& van Steenbergen, J. E. (2011). Monitoring the level of government trust, risk perception and intention of the general public to adopt protective measures during the influenza A (H1N1) pandemic in The Netherlands. BMC Public Health, 11, Article 575. https://doi.org/10.1186/1471-2458-11-575

Vaughan, E., \& Tinker, T. (2009). Effective health risk communication about pandemic influenza for vulnerable populations. American Journal of Public Health, 99(S2), S324S332. https://doi.org/10.2105/AJPH.2009.162537

Vigoda-Gadot, E., \& Talmud, I. (2010). Organizational politics and job outcomes: The moderating effect of trust and social support. Journal of Applied Social Psychology, 40(11), 28292861. https://doi.org/10.1111/j.1559-1816.2010.00683.x

Voeten, H. A., de Zwart, O., Veldhuijzen, I. K., Yuen, C., Jiang, X., Elam, G., Abraham, T., \& Brug, J. (2009). Sources of information and health beliefs related to SARS and avian influenza among Chinese communities in the United Kingdom and The Netherlands, compared to the general population in these countries. International Journal of Behavioral Medicine, 16(1), 49-57. https://doi.org/10.1007/s12529008-9006-4

Vos, S. C., \& Buckner, M. M. (2016). Social media messages in an emerging health crisis: Tweeting bird flu. Journal of Health Communication, 21(3), 301308. https://doi.org/10.1080/10810730.2015.1064495 
Weinstein, N. D. (1980). Unrealistic optimism about future life events. Journal of Personality and Social Psychology, 39(5), 806-820. https://doi.org/10.1037/0022-3514.39.5.806

Weinstein, N. D. (1983). Reducing unrealistic optimism about illness susceptibility. Health Psychology, 2(1), 11-20. https://doi.org/10.1037/0278-6133.2.1.11

Weinstein, N. D., Sandman, P. M., \& Roberts, N. E. (1990). Determinants of self-protective behavior: Home radon testing. Journal of Applied Social Psychology, 20(10), 783-801. https://doi.org/10.1111/j.15591816.1990.tb00379.x

World Health Organization. (2021, March 26). Coronavirus disease 2019 (COVID-19). Retrieved from https://www.who.int/emergencies/diseases/novel-coronavirus-2019/advice-for-public

World Health Organization. (2020a, April 17). Coronavirus disease 2019 (COVID-19). Situation Report-88. Retrieved from https://www.who.int/publications/m/item/situation-report-88

Witte, K. (1992). Putting the fear back into fear appeals: The extended parallel process model. Communications Monographs, 59(4), 329-349. https://doi.org/10.1080/03637759209376276

Witte, K. (1996). Predicting risk behaviors: Development and validation of a diagnostic scale. Journal of Health Communication, 1(4), 317-342. https://doi.org/10.1080/108107396127988

Young, R. M., Oei, T. P. S., \& Crook, G. M. (1991). Development of a drinking self-efficacy questionnaire. Journal of Psychopathology and Behavioral Assessment, 13(1), 115. https://doi.org/10.1007/BF00960735

Young, S. D., \& Rice, E. (2011). Online social networking technologies, HIV knowledge, and sexual risk and testing behaviors among homeless youth. AIDS and Behavior, 15(2), 253260. https://doi.org/10.1007/s10461-010-9810-0

\section{Tables}


Table 1. Profile of participants

\begin{tabular}{|c|c|c|c|}
\hline Demographic item & Categories & Frequency & Percentage \\
\hline & $18-24$ & 168 & 32.8 \\
\hline & $25-34$ & 154 & 30.1 \\
\hline \multirow[t]{5}{*}{ Age (years) } & $35-44$ & 129 & 25.1 \\
\hline & $45-54$ & 47 & 9.2 \\
\hline & 55 and above & 14 & 2.8 \\
\hline & Total & 512 & 100.0 \\
\hline & Female & 302 & 59.0 \\
\hline \multirow[t]{4}{*}{ Sex } & Male & 210 & 41.0 \\
\hline & Total & 512 & 100.0 \\
\hline & Pre-university & 32 & 6.3 \\
\hline & Bachelor's degree & 227 & 44.4 \\
\hline \multirow[t]{4}{*}{ Education level } & Master's degree & 151 & 29.5 \\
\hline & Doctoral degree & 62 & 12.1 \\
\hline & Academician & 40 & 7.7 \\
\hline & Total & 512 & 100.0 \\
\hline \multirow[t]{3}{*}{ Position } & students & 314 & 61.3 \\
\hline & staff & 198 & 38.7 \\
\hline & Total & 512 & 100.0 \\
\hline
\end{tabular}

Note: sample size $=512$ 
Table 2. Common method bias assessment using full collinearity estimates criteria Variables Risk Social Trust in government Self-efficacy perception media usage

$\begin{array}{lllll}\text { VIF } & 1.419 & 1.201 & 1.496 & 2.112\end{array}$

Note: VIF = Variance inflation factor 
Table 3. Measurement model: item loading/weight, construct reliability, and convergent validity

\begin{tabular}{|c|c|c|c|c|c|c|c|}
\hline $\begin{array}{l}\text { First-order } \\
\text { constructs }\end{array}$ & $\begin{array}{l}\text { Second-order } \\
\text { constructs }\end{array}$ & Items & Scale & $\begin{array}{l}\text { Loading/ } \\
\text { weight }\end{array}$ & CR/VIF & $\begin{array}{l}\text { AVE/ } \\
t \\
\text { value }\end{array}$ & $\begin{array}{l}p- \\
\text { value }\end{array}$ \\
\hline \multirow{4}{*}{$\begin{array}{l}\text { Risk } \\
\text { perception }\end{array}$} & & RSP1 & reflective & 0.882 & 0.916 & 0.732 & NA \\
\hline & & RSP2 & & 0.900 & & & \\
\hline & & RSP3 & & 0.878 & & & \\
\hline & & RSP4 & & 0.756 & & & \\
\hline \multirow{2}{*}{$\begin{array}{l}\text { Reflective } \\
\text { quality }\end{array}$} & & REQ1 & reflective & 0.685 & 0.898 & 0.718 & NA \\
\hline & & REQ2 & & 0.696 & & & \\
\hline \multirow{2}{*}{$\begin{array}{l}\text { Practiced } \\
\text { quality }\end{array}$} & & PRQ1 & reflective & 0.853 & 0.847 & 0.711 & NA \\
\hline & & PRQ2 & & 0.770 & & & \\
\hline \multirow{3}{*}{$\begin{array}{l}\text { Advocated } \\
\text { quality }\end{array}$} & & ADQ1 & reflective & 0.807 & 0.883 & 0.715 & NA \\
\hline & & ADQ2 & & 0.855 & & & \\
\hline & & ADQ3 & & 0.838 & & & \\
\hline \multirow{7}{*}{$\begin{array}{l}\text { Stimulated } \\
\text { quality }\end{array}$} & & STQ1 & reflective & 0.859 & 0.896 & 0.715 & NA \\
\hline & & STQ2 & & 0.864 & & & \\
\hline & & STQ3 & & 0.735 & & & \\
\hline & $\begin{array}{l}\text { social media } \\
\text { content quality }\end{array}$ & $\begin{array}{l}\text { reflective } \\
\text { quality }\end{array}$ & formative & 0.315 & 1.461 & 3.793 & 0.000 \\
\hline & & $\begin{array}{l}\text { practiced } \\
\text { quality }\end{array}$ & & 0.322 & 2.932 & 3.313 & 0.000 \\
\hline & & $\begin{array}{l}\text { advocated } \\
\text { quality }\end{array}$ & & 0.411 & 1.264 & 4.739 & 0.000 \\
\hline & & $\begin{array}{l}\text { stimulated } \\
\text { quality }\end{array}$ & & 0.402 & 1.462 & 4.280 & 0.000 \\
\hline \multirow{2}{*}{$\begin{array}{l}\text { Trust in } \\
\text { government }\end{array}$} & & TRA1 & reflective & 0.863 & 0.851 & 0.658 & NA \\
\hline & & TRA2 & & 0.686 & & & \\
\hline
\end{tabular}




\begin{tabular}{llllll} 
& TRA3 & 0.872 & & & \\
\hline Self-efficacy & SEF1 & 0.898 & 0.911 & 0.809 & NA \\
\hline SEF2 & 0.906 & & & \\
\hline SEF3 & 0.921 & \\
\hline SEF4 & 0.893 & \\
\hline SEF5 & 0.877 & \\
\hline
\end{tabular}

Notes: $\mathrm{CR}=$ composite reliability; VIF = variance inflation factor; $\mathrm{AVE}=$ average variance extracted; NA = not applicable.

Table 4. Descriptive statistics, correlation matrix, and discriminant validity

\begin{tabular}{llllllllll}
\hline Variables & Mean & SD & $\mathbf{1}$ & $\mathbf{2}$ & $\mathbf{3}$ & $\mathbf{4}$ & $\mathbf{5}$ & $\mathbf{6}$ & $\mathbf{7}$ \\
\hline 1. Risk perception & 5.885 & 1.190 & $\mathbf{0 . 8 5 6}$ & & & & & \\
\hline 2. Self-efficacy & 6.072 & 1.060 & 0.386 & $\mathbf{0 . 8 9 9}$ & & & & \\
\hline $\begin{array}{l}\text { 3. Social media } \\
\text { content }\end{array}$ & 5.746 & 1.473 & 0.523 & 0.588 & $\mathbf{0 . 9 0 1}$ & & & \\
\hline $\begin{array}{l}\text { 4. Trust in } \\
\text { government }\end{array}$ & 4.322 & 0.677 & 0.539 & 0.470 & 0.480 & $\mathbf{0 . 9 6 9}$ & & \\
\hline 5. Age & 2.280 & 1.092 & 0.405 & 0.307 & 0.253 & 0.030 & NA & \\
\hline 6. Sex & 1.498 & 0.606 & -0.119 & -0.005 & -0.134 & -0.037 & -0.028 & NA \\
\hline 7. Education & 2.705 & 1.022 & 0.149 & 0.184 & 0.161 & 0.168 & 0.618 & -0.060 & NA \\
\hline
\end{tabular}

Note: $\mathrm{SD}=$ standard deviation; NA = not applicable. Bold values on the diagonal are the square root values of the extracted average variance, shared between the constructs and their respective measures. Off-diagonal elements below the diagonal are correlations among the constructs, where values between 0.12 and 0.15 are significant at $p<0.05$, and values of 0.16 or higher are significant at $\mathrm{p}<0.01$ (two-tailed test). 
Page 28/34 
Table 5. Structural path analysis: direct, indirect, and interaction effects

Bias and corrected bootstrap (95\%

$\mathrm{Cl})$

\begin{tabular}{|c|c|c|c|c|c|c|c|c|}
\hline Hypothesis & Direct Effect & $\begin{array}{l}\text { Std } \\
\text { beta }\end{array}$ & $\begin{array}{l}\text { Std } \\
\text { error }\end{array}$ & $\begin{array}{l}t \\
\text { value }\end{array}$ & $\begin{array}{l}p- \\
\text { value }\end{array}$ & $\begin{array}{l}\mathrm{LL} \\
95 \% \\
\mathrm{Cl}\end{array}$ & $\begin{array}{l}\text { UL } \\
95 \% \\
\mathrm{Cl}\end{array}$ & Decision \\
\hline $\mathrm{H}-1$ & $\begin{array}{l}\text { Risk } \\
\text { Perception }{ }^{\circledR} \text { Self- } \\
\text { Efficacy }\end{array}$ & 0.533 & 0.130 & 4.104 & 0.000 & 0.286 & 0.723 & Supported \\
\hline $\mathrm{H}-2$ & $\begin{array}{l}\text { Risk } \\
\text { Perception } ® \text { Trust } \\
\text { in Government }\end{array}$ & 0.283 & 0.100 & 2.832 & 0.002 & 0.121 & 0.441 & Supported \\
\hline
\end{tabular}

\section{Control}

Variables

\begin{tabular}{|c|c|c|c|c|c|c|c|c|}
\hline- & $\begin{array}{l}\text { Age-> Trust in } \\
\text { Authority }\end{array}$ & -0.294 & 0.127 & 0.316 & 0.310 & -0.434 & 0.083 & NS \\
\hline- & $\begin{array}{l}\text { Sex-> Self- } \\
\text { Efficacy-> Trust } \\
\text { in Authority }\end{array}$ & 0.009 & 0.046 & 1.166 & 0.215 & -0.027 & 0.176 & NS \\
\hline- & $\begin{array}{l}\text { Education level-> } \\
\text { Trust in Authority }\end{array}$ & 0.001 & 0.051 & 0.258 & 0.423 & 0.022 & -0.214 & NS \\
\hline- & $\begin{array}{l}\text { Age-> Self- } \\
\text { Efficacy }\end{array}$ & 0.095 & 0.032 & 0.021 & 0.221 & -0.011 & 0.312 & NS \\
\hline- & $\begin{array}{l}\text { Sex-> Self- } \\
\text { Efficacy-> Self- } \\
\text { Efficacy }\end{array}$ & 0.007 & 0.012 & 0.112 & 0.322 & -0.021 & 0.242 & NS \\
\hline- & $\begin{array}{l}\text { Education level-> } \\
\text { Self-Efficacy }\end{array}$ & 0.081 & 0.034 & 1.108 & 0.281 & 0.011 & -0.254 & NS \\
\hline
\end{tabular}

Bias and corrected bootstrap $(95 \%$

$\mathrm{Cl})$

\begin{tabular}{|c|c|c|c|c|c|c|c|c|}
\hline Hypothesis & Interaction Effect & $\begin{array}{l}\text { Std } \\
\text { Beta }\end{array}$ & $\begin{array}{l}\text { Std } \\
\text { Error }\end{array}$ & $\begin{array}{l}t \\
\text { value }\end{array}$ & $p-$ & $\begin{array}{l}\text { LL } \\
95 \% \\
\mathrm{Cl}\end{array}$ & $\begin{array}{l}\text { UL } \\
95 \% \\
\mathrm{Cl}\end{array}$ & Decision \\
\hline $\mathrm{H}-3 \mathrm{a}$ & $\begin{array}{l}\text { RIP*SMUßTrust } \\
\text { in Government }\end{array}$ & 0.210 & 0.092 & 2.289 & 0.001 & 0.030 & 0.342 & Supported \\
\hline $\mathrm{H}-3 \mathrm{~b}$ & $\begin{array}{l}\text { RIP*SMUßSelf- } \\
\text { Efficacy }\end{array}$ & 0.506 & 0.142 & 3.571 & 0.000 & 0.257 & 0.714 & Supported \\
\hline
\end{tabular}

Notes: $\mathrm{N}=512 ;$ bootstrap sample size $=5,000 ; \mathrm{SE}=$ standard error; $\mathrm{LL}=$ lower limit; $\mathrm{Cl}=$ confidence interval; UL = upper limit 95\% bias-correlated Cl; NS = not significant 
Keys: $\mathrm{RIP} * \mathrm{SMU} \circledast$ Trust in Government $=$ Risk Perception $\star$ Social Media content quality ${ }^{\circledR}$ Trust in Government, RIP ${ }^{\star S M U}{ }^{\circledR S e l f-E f f i c a c y}=$ Risk Perception ${ }^{\star S}$ Social Media content quality ${ }^{\circledR S e l f-E f f i c a c y}$

\section{Appendix 1.}


Appendix 1. Questionnaire

\section{Risk Perception:}

1. How likely do you think it is that you might get infected with COVID-19 (Coronavirus SARS-CoV-2) in the near future?

2. If I get the COVID-19 (Coronavirus SARS-CoV-2), it will be severe.

3. If I get the COVID-19 (Coronavirus SARS-CoV-2), it will be risky.

4. If I get the COVID-19 (Coronavirus SARS-CoV-2), I would not be able to manage daily activities.

\section{Trust in Government:}

1. During the current pandemic, the government cares about the well-being of citizens.

2. During the current pandemic, the government keeps its promises.

3. During the current pandemic, the government carries out its duties effectively.

\section{Self- Efficacy:}

1. I am confident in my ability to protect myself from the COVID-19 (Coronavirus SARS-CoV-2)

2. I am certain that I will take required actions even if they are difficult or inconvenient.

3. I have the willpower to engage in precautionary actions.

4. I am confident that I can carry out precautionary actions.

5. I am certain that I can control myself to reduce the chances of getting the COVID-19 (Coronavirus SARS-CoV-2).

6. I am confident in my ability to protect myself from the COVID-19 (Coronavirus SARS-CoV-2)

\section{Perceived Social Media Content Quality:}

(1) Reflective Quality:

1. The outstanding content related to COVID-19 shared on social media can serve my needs well (e.g., using a mask, social distance, etc.).

2. I can do many things with excellent content related to COVID-19 on social media such as sharing with my family members and friends.

(2) Stimulated quality:

I feel positive that the excellent content regarding COVID-19 on my social media account can be helpful when I need it. 
1. I have faith in the outstanding content relating to COVID-19 of my social media account that it can meet my needs.

2.

3. I am optimistic that the superior content regarding COVID-19 of my social media account can be useful for my purposes.

(3) Practiced Quality:

1. I feel positive that the excellent information of COVID-19 on social media can be helpful when I need that very fast and free.

2. I have faith in the outstanding content of COVID-19 on social media that it can meet my needs whenever I can.

(4) Advocated Quality:

1. I would talk openly about COVID-19 using my social media account.

2. I would join an active group to speak about COVID-19 using my social media account.

3. I would speak publicly sharing any information I think can be useful for others using the outstanding content obtained from social media.

\section{Figures}

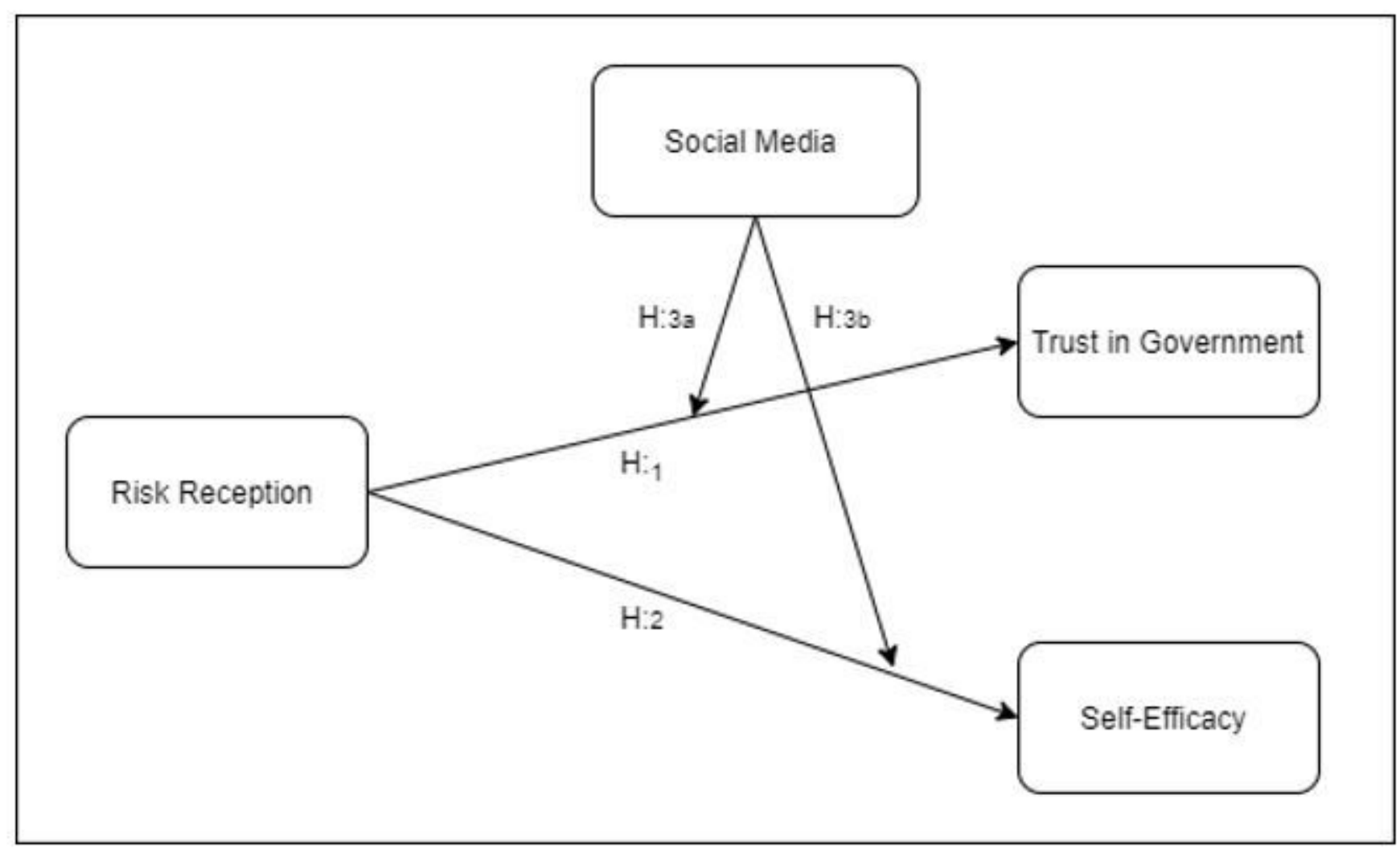

Figure 1 
Research framework

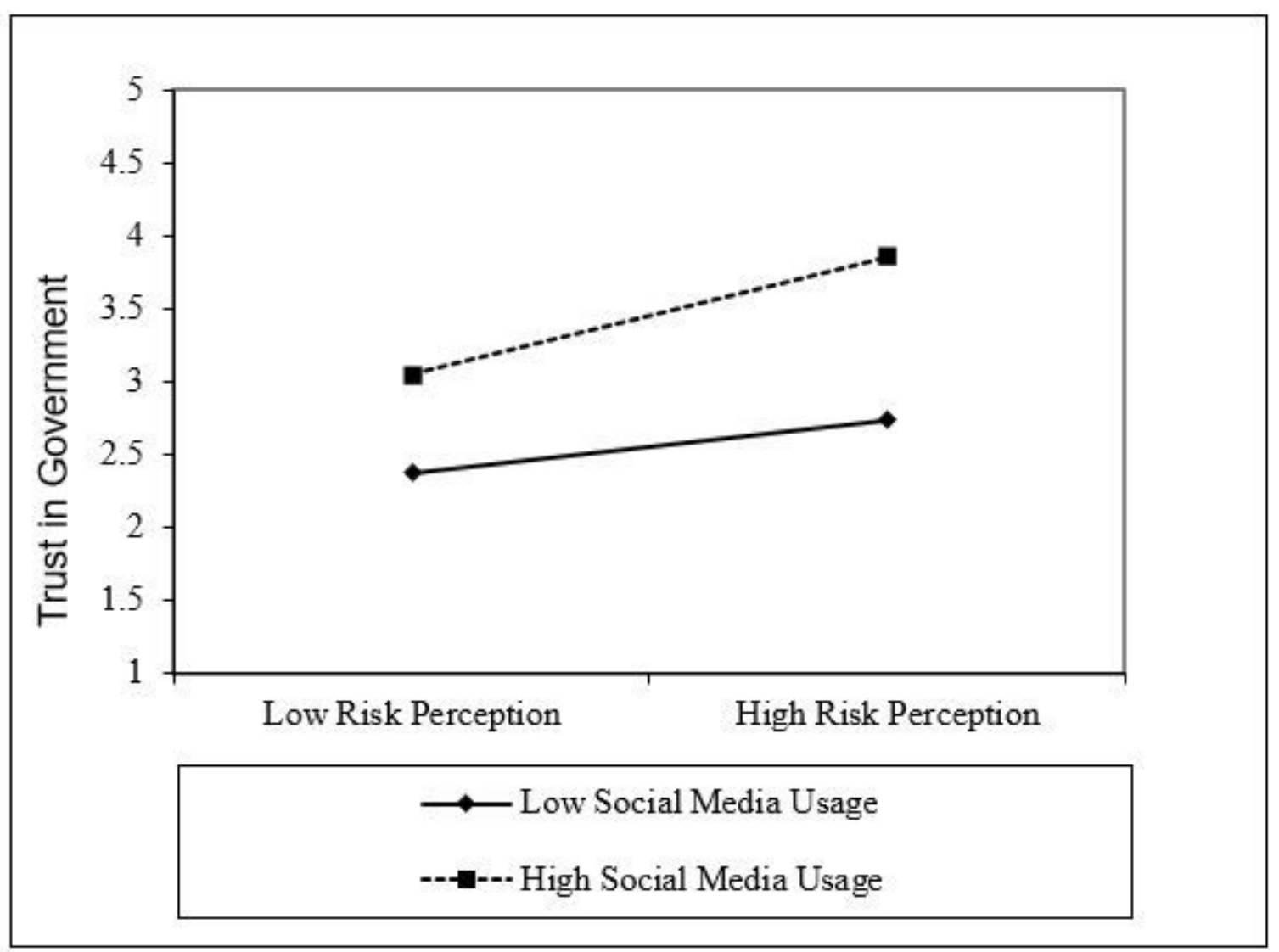

Figure 2

Interaction plot of risk perception $\mathrm{x}$ effect of social media usage on trust in government 


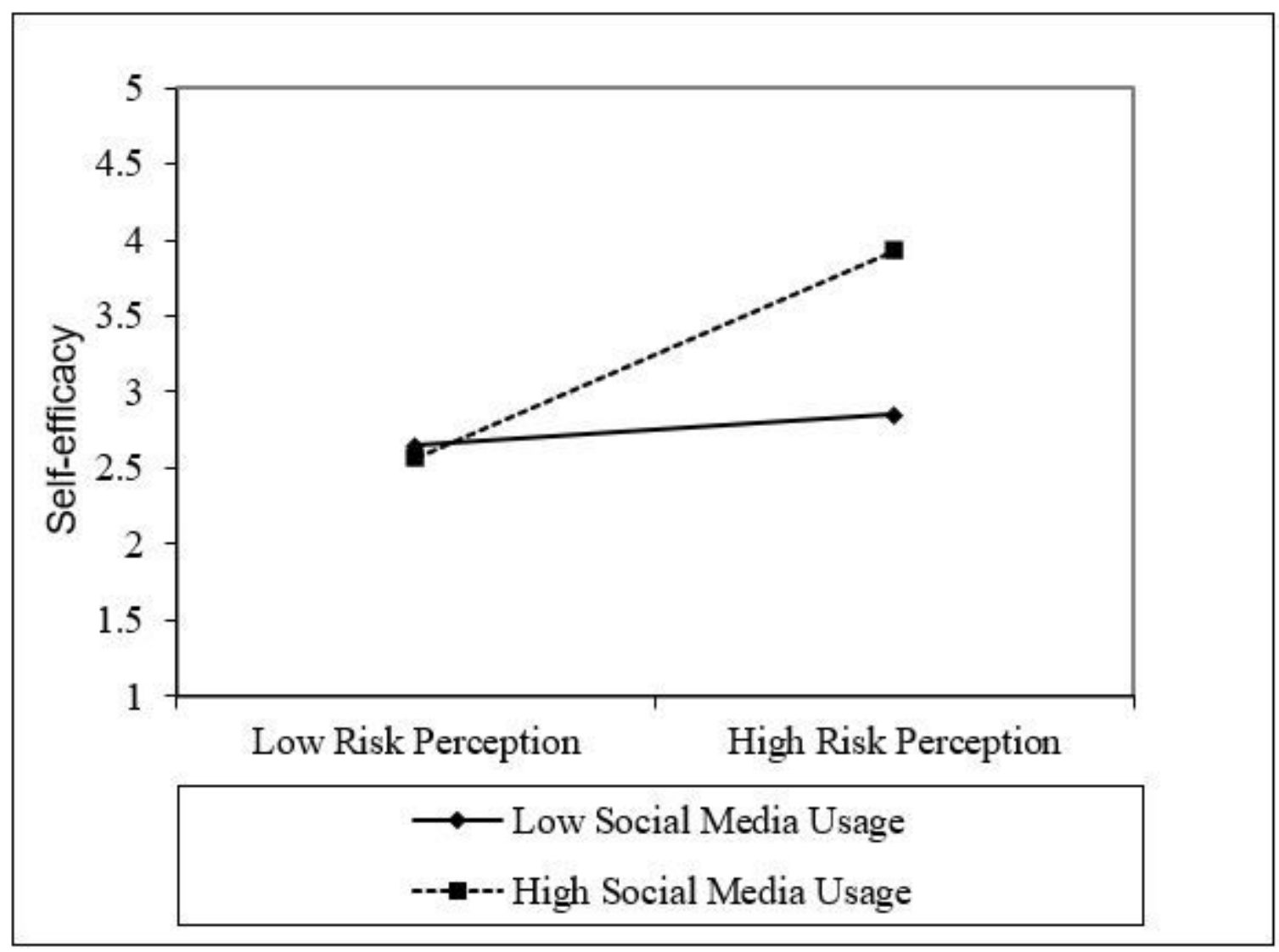

Figure 3

Interaction plot of risk perception $x$ social media usage on self-efficacy 